\title{
Cardioprotective effects and the mechanisms of terminal warm blood cardioplegia in pediatric cardiac surgery
}

\author{
Yoshiya Toyoda, MD ${ }^{a, b}$ \\ Masahiro Yamaguchi, MD \\ Naoki Yoshimura, $\mathrm{MD}^{\mathrm{a}}$ \\ Shigeteru Oka, MDa \\ Yutaka Okita, MD
}

Objectives: Terminal warm blood cardioplegia has been shown to enhance myocardial protection in adult patients. However, the cardioprotective effects and the mechanisms of terminal warm blood cardioplegia in pediatric heart surgery were still unknown.

Methods: One hundred three consecutive patients were prospectively randomized to one of two groups. In the control group $(\mathrm{n}=52)$, myocardial protection was achieved with intermittent hyperkalemic cold blood cardioplegia and topical cardiac cooling. In the terminal warm blood cardioplegia group $(n=51)$, this was supplemented with terminal warm blood cardioplegia before the aorta was declamped. Arterial and coronary sinus blood samples were analyzed to determine myocardial energy metabolism and tissue injury.

Results: There were no significant differences between the two groups in age (5.5 \pm 0.6 years in the control group vs $5.6 \pm 0.5$ years in the terminal warm blood cardioplegia group), body weight (17.2 $\pm 1.4 \mathrm{~kg}$ in the control group vs $19.8 \pm 1.7$ $\mathrm{kg}$ in the terminal warm blood cardioplegia group), percentage of cyanotic heart diseases $(50 \%$ in the control group vs $51 \%$ in the terminal warm blood cardioplegia group), number of patients who required right ventriculotomy (33\% in the control group vs $39 \%$ in the terminal warm blood cardioplegia group), cardiopulmonary bypass time (194 \pm 12.1 minutes in the control group vs $177 \pm 8.6$ minutes in the terminal warm blood cardioplegia group), aortic crossclamp time (83.3 \pm 5.9 minutes in the control group vs $82.3 \pm 5$ minutes in the terminal warm blood cardioplegia group), lowest rectal temperature $\left(27.4 \pm 0.3^{\circ} \mathrm{C}\right.$ in the control group vs $28.1 \pm 0.3^{\circ} \mathrm{C}$ in the terminal warm blood cardioplegia group), and myocardial temperature $\left(9.6 \pm 0.6^{\circ} \mathrm{C}\right.$ in the control group vs $9.6 \pm 0.7^{\circ} \mathrm{C}$ in the terminal warm blood cardioplegia group). Spontaneous defibrillation occurred after reperfusion in $80 \%$ in the terminal warm blood cardioplegia group, which was significantly $(P<$ $.05)$ higher than the control group (62\%). The lactate extraction rate at 60 minutes of reperfusion was significantly $(P<.05)$ higher in the terminal warm blood cardioplegia group $(9.0 \pm 2.8 \%)$ than the control group $(-3.3 \pm 2.4 \%)$. The postreperfusion values of cardiac troponin $\mathrm{T}(7.4 \pm 0.6 \mathrm{ng} / \mathrm{mL}$ vs $11.2 \pm 1.0 \mathrm{ng} / \mathrm{mL}$ at 6 hours; $4.6 \pm 0.6 \mathrm{ng} / \mathrm{mL}$ vs $9.3 \pm 1.6 \mathrm{ng} / \mathrm{mL}$ at 18 hours) and heart-type fatty acid binding protein $(137 \pm 28 \mathrm{ng} / \mathrm{mL}$ vs $240 \pm 30 \mathrm{ng} / \mathrm{mL}$ at 2 hours; $88 \pm 19$ $\mathrm{ng} / \mathrm{mL}$ vs $162 \pm 26 \mathrm{ng} / \mathrm{mL}$ at 3 hours) were significantly $(P<.05$ vs the control group) lower in the terminal warm blood cardioplegia group.

Conclusion: Terminal warm blood cardioplegia enhances myocardial protection in pediatric cardiac surgery by an improvement in aerobic energy metabolism and a reduction of myocardial injury or necrosis. 


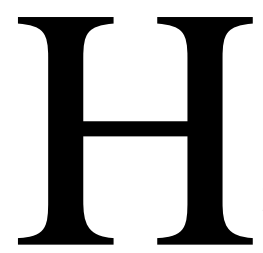

ypothermia continues to be the standard method for myocardial protection in heart surgery since the 1950 s. ${ }^{1-3}$ Previously, we also have shown that hypothermia is important for myocardial protection in pediatric heart surgery, especially in cyanotic heart diseases in which the noncoronary collateral vessel flow may contribute to myocardial rewarming and in that way increase ischemic injury. ${ }^{4}$ Although hypothermia reduces oxygen demands, thereby prolonging tolerable ischemic arrest time, hypothermia is also reported to be associated with detrimental effects on enzymatic and metabolic function. $^{5}$

Recent evidence obtained in adult patients demonstrated that warm heart surgery might provide better protection for surgical ischemia/reperfusion injury. ${ }^{5}$ Teoh and associates ${ }^{6}$ demonstrated in a prospective, randomized trial in patients undergoing elective coronary artery bypass that terminal warm blood cardioplegia (TWBCP) enhanced myocardial protection afforded by intermittent cold blood cardioplegia. TWBCP is now often used in adult heart surgery but is rarely used in pediatric heart surgery. ${ }^{7}$ Because developmental differences exist in myocardial metabolism and response to ischemia/reperfusion, ${ }^{1}$ the effects of TWBCP in pediatric heart surgery need to be elucidated. The purpose of this study was to determine the cardioprotective effects and the mechanisms of TWBCP in pediatric heart surgery.

\section{Methods}

\section{Patient Population}

One hundred three consecutive patients undergoing heart surgery for congenital heart diseases at Kobe Children's Hospital between July 1997 and September 1998 were prospectively randomized to one of two groups. The control group $(\mathrm{C}, \mathrm{n}=52)$ received cold blood cardioplegia for myocardial protection. The terminal warm blood cardioplegia group $(\mathrm{T}, \mathrm{n}=51$ ) received cold blood cardioplegia with terminal warm blood cardioplegia. The patients' ages were $5.6 \pm 0.4$ years ranging from 0 to 18 years, and the body weight was $18.4 \pm 1.1 \mathrm{~kg}$. The two groups were similar with respect to disease, and about half of the patients in both groups had cyanosis. Preoperative patient characteristics are summarized in Table 1.

\section{Operative Procedure}

Anesthesia was induced and maintained with fentanyl (50 to 100 $\mu \mathrm{g} / \mathrm{kg}$ ) and vecuronium. Patients were ventilated with oxygen, air, and isoflurane, and ventilation was adjusted to maintain normocarbia. Cardiopulmonary bypass was instituted with an ascending aortic cannula, bicaval venous cannulas, and a systemic ventricular vent. Systemic flow was maintained between 2.2 and $2.6 \mathrm{~L} /$ minute/ $\mathrm{m}^{2}$, and mean arterial pressure between 40 and $60 \mathrm{~mm} \mathrm{Hg}$. Moderate systemic hypothermia was used with a lowest rectal temperature of $27.7 \pm 0.2^{\circ} \mathrm{C}$. We have used $\mathrm{pH}$ stat strategy for $\mathrm{pH}$ management by the addition of carbon dioxide as appropriate.
TABLE 1. Patient characteristics

\begin{tabular}{lccc}
\hline & $\begin{array}{c}\text { Control } \\
(\mathbf{n}=\mathbf{5 2})\end{array}$ & $\begin{array}{c}\text { TWBCP } \\
(\mathbf{n}=\mathbf{5 1 )}\end{array}$ & $\boldsymbol{P}$ value \\
\hline Age (years) & & & \\
$\quad$ mean & $5.5 \pm 0.6$ & $5.6 \pm 0.5$ & .867 \\
$\quad$ range & $0-13$ & $0-18$ & \\
Body weight (kg) & $17.2 \pm 1.4$ & $19.8 \pm 1.7$ & .243 \\
Sex, (M/F) & $27 / 25$ & $33 / 18$ & .232 \\
Pathology, (n) & & & \\
Acyanotic & 26 & 25 & \\
$\quad$ VSD, ASD & 20 & 22 & \\
$\quad$ Aortic or mitral valve & 4 & 2 & \\
$\quad$ Others & 2 & 1 & \\
Cyanotic & 26 & 26 & \\
TF with PS or PA & 11 & 15 & \\
TGA & 5 & 1 & \\
TAPVR & 0 & 2 & \\
SV & 5 & 4 & \\
Others & 5 & 4 & \\
\hline
\end{tabular}

Data are shown as the mean \pm standard error of the mean for age and body weight, or the actual number for the rest of the parameters.

$V S D$, Ventricular septal defect; $A S D$, atrial septal defect; $T F$, tetralogy of Fallot; $P S$, pulmonary artery stenosis; $P A$, pulmonary atresia; TGA, transposition of great arteries; TAPVR, total anomalous pulmonary venous return; $S V$, single ventricle.

\section{Protocol of Myocardial Protection}

Myocardial protection was achieved with intermittent cold blood cardioplegia with topical heart cooling in all patients. Cardioplegic solution of $300 \mathrm{~mL} / \mathrm{m}^{2}$ of body surface area was initially infused into the aortic root at $30 \mathrm{~mm} \mathrm{Hg}$ to achieve cardiac arrest, with subsequent doses of $150 \mathrm{~mL} / \mathrm{m}^{2}$ of body surface area every 20 minutes. Blood cardioplegia was made by mixing a hyperkalemic crystalloid solution $^{8}$ with oxygenated blood in a 1:2 dilution and cooled to $9^{\circ} \mathrm{C}$. At the start of reperfusion, the aorta was partially declamped for 3 minutes, and the aortic root pressure was kept less than $30 \mathrm{~mm} \mathrm{Hg}$ to reduce reperfusion injury; then the aorta was fully declamped. In group $\mathrm{T}$, an additional $300 \mathrm{~mL} / \mathrm{m}^{2}$ of body surface area of warm $\left(35^{\circ} \mathrm{C}\right)$ blood cardioplegia was infused into the aortic root at a pressure of $30 \mathrm{~mm} \mathrm{Hg}$ just before declamping the aorta. The composition of terminal warm blood cardioplegia was the same as the cold blood cardioplegia, other than temperature, and is shown in Table 2.

Electrical defibrillation was applied to the heart if ventricular fibrillation persisted beyond 3 minutes after declamping the aorta. We avoided inotropic support as much as possible before coming off from cardiopulmonary bypass, but if systolic blood pressure was less than 50 to $70 \mathrm{~mm} \mathrm{Hg}$, depending on the patient's age, with left atrial pressure between 10 and $12 \mathrm{~mm} \mathrm{Hg}$, inotropic support was initiated even during cardiopulmonary bypass. After weaning from cardiopulmonary bypass, if systolic blood pressure was lower than 60 to $80 \mathrm{~mm} \mathrm{Hg}$ or urine output was less than 1 $\mathrm{mL} / \mathrm{kg} /$ hour, we started inotropic support after optimizing rhythm, afterload, and preload with left atrial pressure between 10 and 12 $\mathrm{mm} \mathrm{Hg}$. 


\section{TABLE 2. Composition of TWBCP}

\begin{tabular}{lr}
\hline $\mathrm{Na}^{+}(\mathrm{mmol} / \mathrm{L})$ & $97.7 \pm 1.2$ \\
$\mathrm{~K}^{+}(\mathrm{mmol} / \mathrm{L})$ & $18.7 \pm 0.3$ \\
$\mathrm{Cl}^{-}(\mathrm{mmol} / \mathrm{L})$ & $90.4 \pm 0.8$ \\
$\mathrm{Mg}^{2+}(\mathrm{mmol} / \mathrm{L})$ & $1.0 \pm 0.01$ \\
$\mathrm{Ca}^{2+}(\mathrm{mmol} / \mathrm{L})$ & $0.73 \pm 0.01$ \\
$\mathrm{pH}$ & $7.51 \pm 0.01$ \\
$\mathrm{HCO}^{-}(\mathrm{mmol} / \mathrm{L})$ & $17.4 \pm 0.3$ \\
Hematocrit $(\%)$ & $18.6 \pm 0.6$ \\
Osmolarity (mOsm/L) & $339 \pm 3.1$
\end{tabular}

All data are shown as the mean \pm standard error of the mean for each composition.

\section{Measurements}

Myocardial temperature was measured at the ventricular septum near the cardiac apex just before release of the aortic crossclamp using a needle thermistor. Hemodynamic measurements included heart rate, blood pressure, and left atrial pressure. Arterial and coronary sinus blood samples were taken at $0,10,20,30,45$, and 60 minutes after the aortic crossclamp release and analyzed for blood gas and lactate. Oxygen content was calculated from the hemoglobin $(\mathrm{Hb})$, the $\mathrm{So}_{2}$, and the $\mathrm{Po}_{2}$ according to the equation:

$$
\mathrm{O}_{2} \text { content }=1.34 \times \mathrm{Hb} \times \mathrm{So}_{2}+0.0031 \times \mathrm{Po}_{2}
$$

Myocardial oxygen extraction and myocardial lactate extraction were calculated as the difference between the arterial and coronary sinus content. Lactate extraction rate was calculated by the equation:

$$
\text { Lactate extraction rate }=(\mathrm{La}-\mathrm{Lcs}) \times 100 / \mathrm{La}
$$

As a marker of myocardial injury, serum concentration of cardiac troponin $\mathrm{T}$ and heart-type fatty acid binding protein ( $h$ FABP) were measured. Cardiac troponin $\mathrm{T}$ was measured at 0,1 , 3,6 , and 18 hours after the aortic crossclamp release, and h-FABP at $0,1,2$, and 3 hours. Cardiac troponin $\mathrm{T}$ was measured with an enzyme immunoassay and h-FABP with a sandwich enzyme immunoassay with two different anti-h-FABP monoclonal antibodies. $^{9}$

\section{Assessment of Clinical Outcome}

Intraoperative and postoperative clinical parameters were used to assess clinical outcome. Intraoperative parameters included heartbeat recovery after release of the aortic crossclamp, either spontaneously or with electrical defibrillation, and intraoperative requirement of pacing and inotropes for weaning patients from cardiopulmonary bypass. Postoperative parameters included duration and maximum doses of inotropic support, duration of ventilatory support, intensive care unit stay, and mortality rate. Dopamine was the catecholamine of the first choice and dobutamine was the second. When dopamine and dobutamine failed to provide sufficient inotropic support, epinephrine was used.

\section{Statistics}

Data were collected prospectively and analyzed for all 103 patients recruited. Statistical analysis was performed using SAS version 6.12 software package (SAS Institute, Cary, NC). The mean \pm the standard error of the mean for all data was calculated for all

\begin{tabular}{|c|c|c|c|}
\hline & $\begin{array}{l}\text { Control } \\
(n=52)\end{array}$ & $\begin{array}{l}\text { TWBCP } \\
(n=51)\end{array}$ & $P$ value \\
\hline $\begin{array}{l}\text { Required Right } \\
\text { Ventriculotomy (\%) }\end{array}$ & 33 & 39 & .314 \\
\hline CPB time (minutes) & $194 \pm 12.1$ & $177 \pm 8.6$ & .281 \\
\hline AoX time (minutes) & $83.3 \pm 5.9$ & $82.3 \pm 5.0$ & .905 \\
\hline $\begin{array}{l}\text { Lowest rectal temperature } \\
\text { during } \mathrm{CPB}\left({ }^{\circ} \mathrm{C}\right)\end{array}$ & $27.4 \pm 0.3$ & $28.1 \pm 0.3$ & .076 \\
\hline Myocardial temperature $\left({ }^{\circ} \mathrm{C}\right)$ & $9.6 \pm 0.6$ & $9.6 \pm 0.7$ & .997 \\
\hline $\begin{array}{l}\text { Spontaneous beat after } \\
\text { declamping }(\%)\end{array}$ & 62 & 80 & .029 \\
\hline $\begin{array}{l}\text { Pacing at weaning from } \\
\text { CPB }(\%)\end{array}$ & 25 & 16 & .177 \\
\hline $\begin{array}{l}\text { Inotropes at weaning from } \\
\text { CPB (\%) }\end{array}$ & 15 & 0 & .003 \\
\hline
\end{tabular}

TABLE 3. Summary of intraoperative data

Data are shown as the mean \pm standard error of the mean or the percentage for each group. Myocardial temperature in the group $T$ was the temperature just prior to the start of TWBCP infusion. $C P B$, Cardiopulmonary bypass; $A o X$, aortic crossclamp.

variables. Intragroup analysis was performed by a two-tailed paired $t$ test or repeated measures analysis of variance with Bonferroni posthoc test as appropriate. Intergroup analysis was performed by a two-tailed unpaired $t$ test or repeated measures analysis of variance with Bonferroni post-hoc test as appropriate. A Fisher's exact test was used for categorical variables.

\section{Results \\ Clinical Outcome}

Intraoperative data are shown in Table 3. Right ventriculotomy was required for repair in $33 \%$ of group C and $39 \%$ of the group $\mathrm{T}(P=.314)$. No significant differences were observed between the groups as far as the cardiopulmonary bypass time, the aortic crossclamp time, and the lowest rectal temperature during cardiopulmonary bypass. Myocardial temperature just before release of the aortic crossclamp was $9.6 \pm 0.6^{\circ} \mathrm{C}$ in group $\mathrm{C}$ and the temperature just before the start of TWBCP infusion was $9.6 \pm 0.7^{\circ} \mathrm{C}$ (NS vs group $\mathrm{T})$. In group $\mathrm{T}$, infusion of TWBCP significantly increased myocardial temperature from $9.6 \pm 0.7^{\circ} \mathrm{C}$ to $20.0 \pm 0.7^{\circ} \mathrm{C}$ $(P<.001)$. Spontaneous defibrillation occurred within minutes after release of the aortic crossclamp in $80 \%$ of the patients receiving TWBCP, which was significantly $(P=$ .029) greater than the control. Ventricular pacing was required for weaning patients from cardiopulmonary bypass in $25 \%$ of group $\mathrm{C}$ and $16 \%$ of group $\mathrm{T}(P=.177)$, and inotropes were required for $15 \%$ in group $\mathrm{C}$ whereas no patients required inotropes in group $\mathrm{T}(P=.003)$. In the intensive care unit, however, inotropic support was required for 47 of 52 patients $(90.4 \%)$ in group $C$ and 49 of 51 patients $(96.1 \%)$ in group $\mathrm{T}(P=.437)$.

Postoperative data are shown in Table 4. All clinical outcome parameters including systemic ventricular ejection 
TABLE 4. Summary of postoperative data

\begin{tabular}{lccc}
\hline & $\begin{array}{c}\text { Control } \\
(\mathbf{n}=\mathbf{5 2})\end{array}$ & $\begin{array}{c}\text { TWBCP } \\
(\mathbf{n}=\mathbf{5 1})\end{array}$ & $\boldsymbol{P}$ value \\
\hline $\begin{array}{l}\text { Inotropic support duration } \\
\text { (hours) }\end{array}$ & $94.9 \pm 10.5$ & $88.2 \pm 9.7$ & .641 \\
Maximum doses of & & & \\
$\quad$ Inotrope ( $\mu \mathrm{g} / \mathrm{kg} / \mathrm{min})$ & & & \\
$\quad$ Dopamine & $8.4 \pm 0.6$ & $7.7 \pm 0.4$ & .320 \\
$\quad$ Dobutamine & $3.2 \pm 0.5$ & $1.8 \pm 0.5$ & .075 \\
$\quad$ Epinephrine & $0.023 \pm 0.008$ & $0.015 \pm 0.005$ & .421 \\
Ventilatory support & $67.8 \pm 12.8$ & $61.8 \pm 9.5$ & .706 \\
$\quad$ duration (hours) & & & \\
ICU stay (days) & $7.1 \pm 0.9$ & $5.8 \pm 0.6$ & .263 \\
Mortality (\%) & 7.7 & 2.0 & .187 \\
\hline
\end{tabular}

Data are shown as the mean \pm standard error of the mean or the percentage for mortality rate. $I C U$, Intensive care unit.

fraction, duration and maximum doses of inotropic support, ventilatory support, intensive care unit stay, and mortality rate were better for patients receiving TWBCP compared with the control group, although no statistical significance was observed between the groups.

\section{Myocardial Oxygen and Lactate Extraction}

No significant difference in myocardial oxygen extraction was observed between the groups throughout the initial 60 minutes of reperfusion (Figure 1). However, myocardial lactate extraction rate was increased at all time points in group $\mathrm{T}$ compared with group $\mathrm{C}$ (Figure 2). The lactate extraction rate at 60 minutes of reperfusion was significantly $(P=.004)$ higher in group $\mathrm{T}(9.0 \pm 2.8 \%)$ than group $\mathrm{C}(-3.3 \pm 2.4 \%)$.

\section{Cardiac Troponin T and Heart-type Fatty Acid Binding Protein}

Serum concentrations of cardiac troponin $\mathrm{T}$ were $7.4 \pm 0.6$ $\mathrm{ng} / \mathrm{mL}$ at 6 hours and $4.6 \pm 0.6 \mathrm{ng} / \mathrm{mL}$ at 18 hours in the TWBCP group, which were significantly $(P<.05)$ lower than $11.2 \pm 1.0 \mathrm{ng} / \mathrm{mL}$ and $9.3 \pm 1.6 \mathrm{ng} / \mathrm{mL}$ in the control group, respectively (Figure 3). No significant differences in serum concentration of h-FABP were observed between the groups immediately and 1 hour after the aortic crossclamp release. However, h-FABP was $137 \pm 28 \mathrm{ng} / \mathrm{mL}$ and $88 \pm$ $19 \mathrm{ng} / \mathrm{mL}$ at 2 and 3 hours, respectively, in group T, which were significantly $(P<.05)$ lower than $240 \pm 30 \mathrm{ng} / \mathrm{mL}$ and $162 \pm 26 \mathrm{ng} / \mathrm{mL}$ at the same time points, respectively, in group C (Figure 4).

\section{Effects of TWBCP in Younger Patients (Age $\leq 2$}

\section{Years)}

We compared 13 patients in group $\mathrm{C}$ and 9 patients in group $\mathrm{T}$ whose ages were equal to or less than 2 years. Patient characteristics are shown in the Table 5. Myocardial lactate

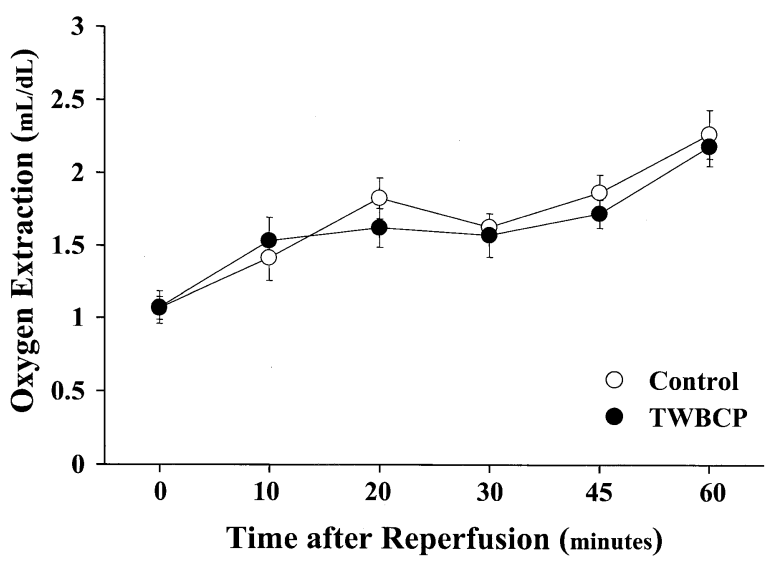

Figure 1. 0xygen extraction during initial 60 minutes of reperfusion after aortic crossclamp release. All results are shown as mean \pm standard error of mean for each group.

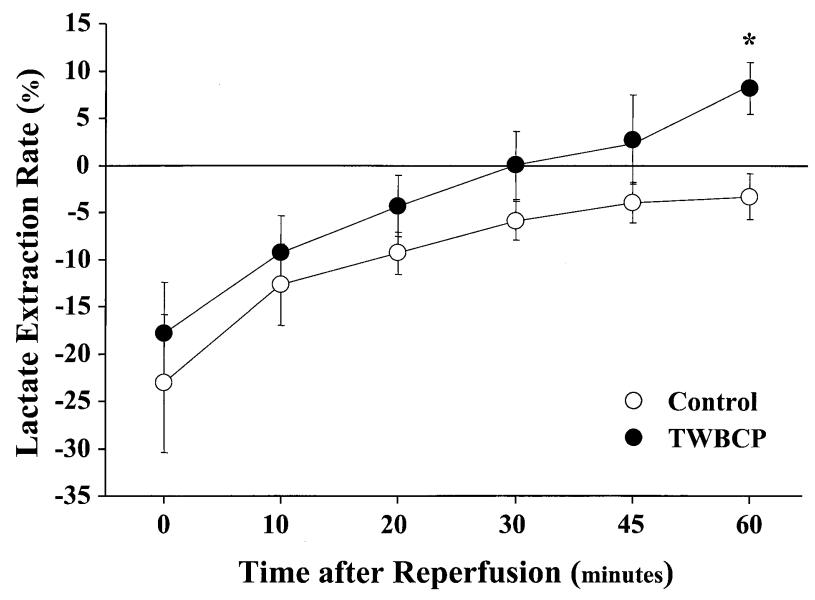

Figure 2. Lactate extraction rate during initial 60 minutes of reperfusion after aortic crossclamp release. All results are shown as mean \pm standard error of mean for each group. Significant differences: ${ }^{*} \boldsymbol{P}<.05$ vs control.

extraction rate was increased at all time points up to 30 minutes of reperfusion in group $\mathrm{T}$ compared with group $\mathrm{C}$ (Figure 5). The lactate extraction rate was $6.4 \pm 1.5 \%$ at 30 minutes of reperfusion in group $\mathrm{T}$, which was significantly $(P=.03)$ higher than $-8.4 \pm 3.7 \%$ in group C. Cardiac troponin $\mathrm{T}$ was decreased in group $\mathrm{T}$ compared with group $\mathrm{C}$ at any time point; however, no statistical significance was observed between the groups because of the small number (Figure 6).

\section{Effects of TWBCP in Patients with Cyanosis}

There were 26 patients with cyanosis in each group. Patient characteristics are shown in Table 6. Significantly fewer patients required inotropes for weaning from cardiopulmo- 


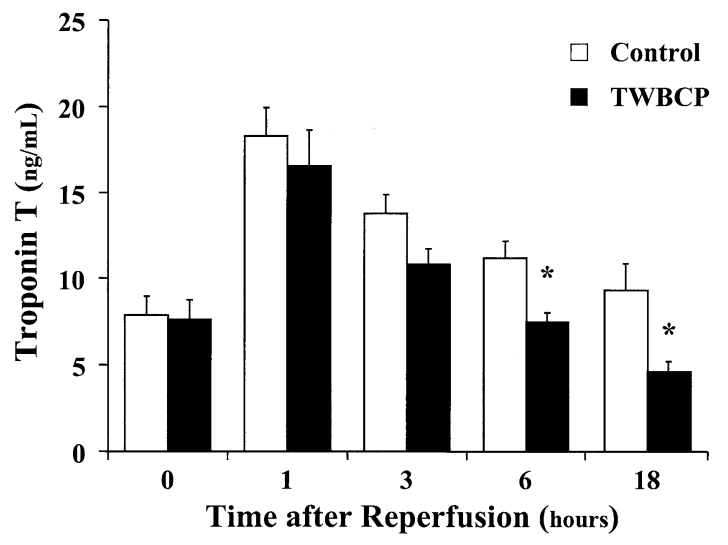

Figure 3. Serum concentration of cardiac troponin T 0, 1, 3, 6, and 18 hours after aortic crossclamp release. All results are shown as mean \pm standard error of mean for each group. Significant differences: ${ }^{*} \boldsymbol{P}<.05$ vs control.

TABLE 5. Patient characteristics (age $\leq 2$ years)

\begin{tabular}{|c|c|c|c|}
\hline & $\begin{array}{l}\text { Control } \\
(n=13)\end{array}$ & $\begin{array}{l}\text { TWBCP } \\
(\mathrm{n}=9)\end{array}$ & $P$ value \\
\hline Age (months) & $10.8 \pm 2.5$ & $15.3 \pm 2.6$ & .241 \\
\hline Body weight $(\mathrm{kg})$ & $6.2 \pm 0.6$ & $8.2 \pm 0.7$ & .042 \\
\hline Cyanotic $(\%)$ & 46 & 22 & .246 \\
\hline CPB time (minutes) & $185 \pm 32$ & $168 \pm 14$ & .676 \\
\hline AoX time (minutes) & $79.1 \pm 11.2$ & $84.4 \pm 10.3$ & .747 \\
\hline $\begin{array}{l}\text { Lowest rectal temperature } \\
\text { during } \mathrm{CPB}\left({ }^{\circ} \mathrm{C}\right)\end{array}$ & $26.9 \pm 0.4$ & $27.3 \pm 0.5$ & .509 \\
\hline Myocardial temperature $\left({ }^{\circ} \mathrm{C}\right)$ & $11.7 \pm 1.9$ & $9.3 \pm 1.6$ & .368 \\
\hline $\begin{array}{l}\text { Spontaneous beat after } \\
\text { declamping }(\%)\end{array}$ & 69 & 89 & .293 \\
\hline $\begin{array}{l}\text { Inotropes at weaning from } \\
\text { CPB }(\%)\end{array}$ & 31 & 0 & .098 \\
\hline $\begin{array}{l}\text { Inotropic support duration } \\
\text { (hours) }\end{array}$ & $103 \pm 16$ & $98 \pm 16$ & .835 \\
\hline $\begin{array}{l}\text { Ventilatory support duration } \\
\text { (hours) }\end{array}$ & $111 \pm 24$ & $91 \pm 19$ & .553 \\
\hline ICU stay (days) & $8.8 \pm 1.7$ & $7.3 \pm 1.0$ & .499 \\
\hline Mortality $(\%)$ & 14 & 0 & .338 \\
\hline
\end{tabular}

Data are shown as the mean \pm standard error of the mean or the percentage of the patients in each group. Myocardial temperature in the group $T$ was the temperature just prior to the start of TWBCP infusion. $C P B$, Cardiopulmonary bypass; $A o X$, aortic crossclamp; ICU, intensive care unit.

nary bypass in group $\mathrm{T}$ compared with group $\mathrm{C}$. The myocardial lactate extraction rate was similar up to 45 minutes of reperfusion between the groups (Figure 7). The lactate extraction rate was $7.6 \pm 2.7 \%$ at 60 minutes of reperfusion in group $\mathrm{T}$, which was significantly $(P=.037)$ higher than $-3.0 \pm 3.4 \%$ in group C. No significant differences in cardiac troponin $\mathrm{T}$ were observed between the groups at any time (Figure 8).

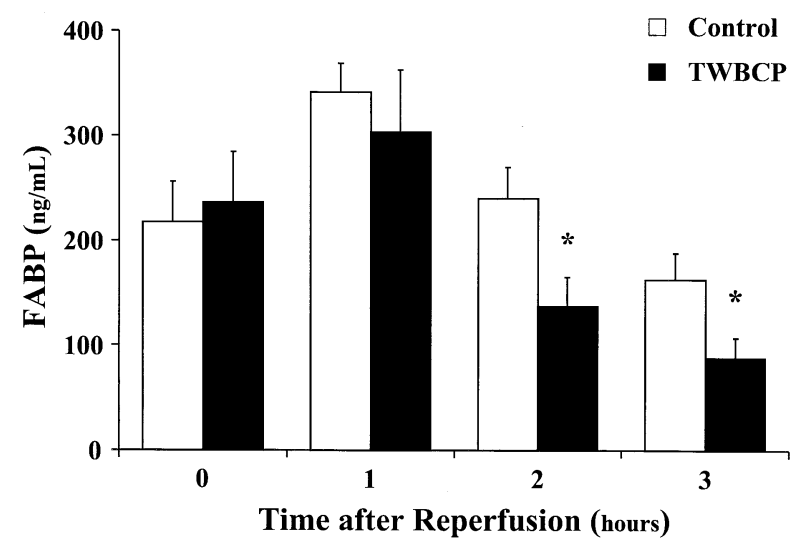

Figure 4. Serum concentration of heart-type fatty acid binding protein (FABP) 0, 1, 2, and 3 hours after the aortic crossclamp release. All results are shown as mean \pm standard error of mean for each group. Significant differences: ${ }^{*} P<.05$ vs control.

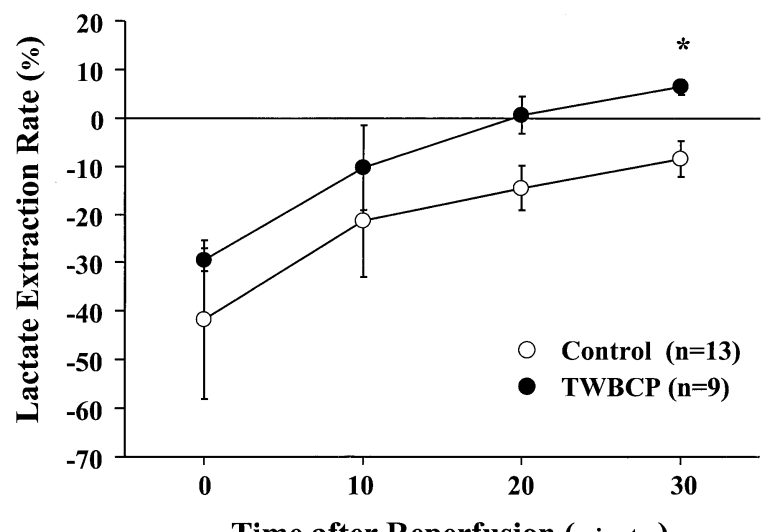

Figure 5. Effects of TWBCP in younger patients (age $\leq 2$ years). Lactate extraction rate during initial 30 minutes of reperfusion after aortic crossclamp release. All results are shown as mean \pm standard error of mean for each group. Significant differences: $* \boldsymbol{P}<.05$ vs control.

\section{Discussion}

In this article, we show the cardioprotective effects and the mechanisms of terminal warm blood cardioplegia in pediatric heart surgery. Our data demonstrated that, with TWBCP, a significantly higher number of hearts resumed normal sinus rhythm spontaneously and all hearts could be weaned from cardiopulmonary bypass with no inotropic support, indicating that TWBCP enhances myocardial protection achieved with cold blood cardioplegia. Our results also show that TWBCP significantly increased lactate extraction rate and significantly decreased serum concentration of cardiac troponin $\mathrm{T}$ and $\mathrm{h}-\mathrm{FABP}$, indicating that the mechanisms by which TWBCP affords cardioprotection include improvement in aerobic energy metabolism and reduction of myocardial injury or necrosis. 


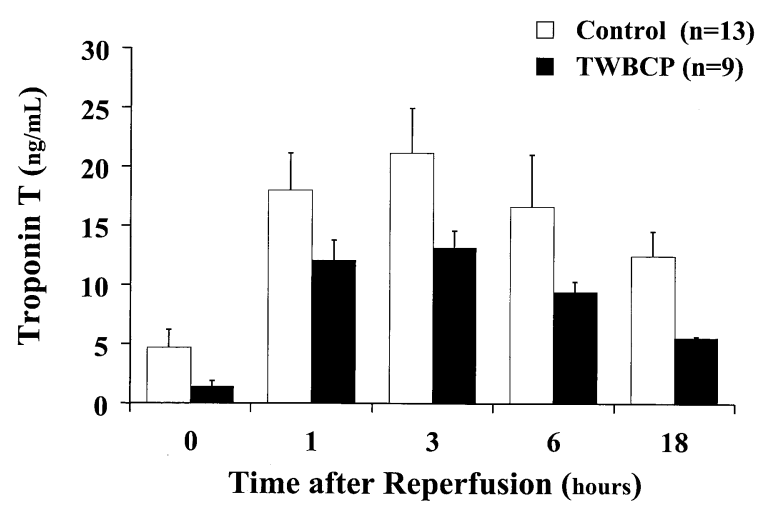

Figure 6. Effects of TWBCP in younger patients (age $\leq 2$ years). Serum concentration of cardiac troponin $T 0,1,3,6$, and 18 hours after aortic crossclamp release. All results are shown as mean \pm standard error of mean for each group.

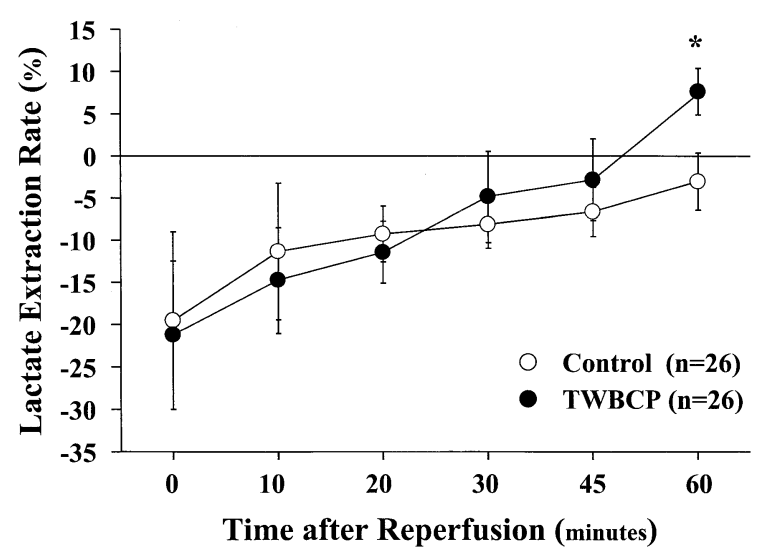

Figure 7. Effects of TWBCP in patients with cyanosis. Lactate extraction rate during initial 60 minutes of reperfusion after aortic crossclamp release. All results are shown as mean \pm standard error of mean for each group. Significant differences: ${ }^{*} \boldsymbol{P}<.05$ versus control.

We have used cardiac troponin $\mathrm{T}$ and $\mathrm{h}-\mathrm{FABP}$ as a marker of myocardial injury because recent reports have suggested that both troponin $\mathrm{T}$ and h-FABP are more sensitive and specific to myocardial injury compared with creatine kinase-MB isoenzyme. ${ }^{9,10}$ Troponin $\mathrm{T}$ is one of three components of troponin that is a major accessory protein associated with actin filaments and mediates $\mathrm{Ca}^{2+}$ regulation of muscle contraction. ${ }^{11}$ Because most cardiac troponin $\mathrm{T}$ is myofibril bound, its release in serum is expected to correlate with the extent of myocardial necrosis. Furthermore, its release beyond several hours is reported to derive from myofibril-bound troponin $\mathrm{T}$ that is compartmented in the cell, but not from cytosolic troponin $\mathrm{T}$ that is released earlier after ischemic events. ${ }^{12}$ Our data showed that serum concentration of troponin $\mathrm{T}$ was significantly

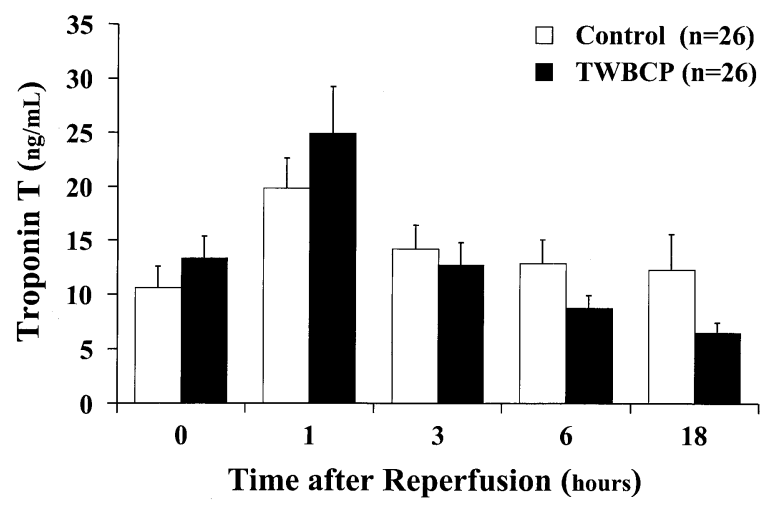

Figure 8. Effects of TWBCP in patients with cyanosis. Serum concentration of cardiac troponin $T$ 0, 1, 3, 6, and 18 hours after aortic crossclamp release. All results are shown as mean \pm standard error of mean for each group.

TABLE 6. Patient characteristics (cyanotic group)

\begin{tabular}{|c|c|c|c|}
\hline & $\begin{array}{c}\text { Control } \\
(\mathrm{n}=26)\end{array}$ & $\begin{array}{l}\text { TWBCP } \\
(n=26)\end{array}$ & $P$ value \\
\hline Age (years) & $6.2 \pm 0.8$ & $5.3 \pm 0.4$ & .293 \\
\hline Body weight (kg) & $17.1 \pm 1.7$ & $16.9 \pm 0.8$ & .909 \\
\hline CPB time (minutes) & $250 \pm 17$ & $214 \pm 10$ & .072 \\
\hline AoX time (minutes) & $97.2 \pm 10.3$ & $88.6 \pm 6.8$ & .488 \\
\hline $\begin{array}{l}\text { Lowest rectal temperature } \\
\text { during } \mathrm{CPB}\left({ }^{\circ} \mathrm{C}\right)\end{array}$ & $26.1 \pm 0.2$ & $26.7 \pm 0.2$ & .082 \\
\hline Myocardial temperature $\left({ }^{\circ} \mathrm{C}\right)$ & $9.5 \pm 0.9$ & $8.2 \pm 0.9$ & .341 \\
\hline $\begin{array}{l}\text { Spontaneous beat after } \\
\text { declamping }(\%)\end{array}$ & 69 & 89 & .087 \\
\hline $\begin{array}{l}\text { Inotropes at weaning from } \\
\text { CPB }(\%)\end{array}$ & 19 & 0 & .025 \\
\hline $\begin{array}{l}\text { Inotropic support duration } \\
\text { (hours) }\end{array}$ & $100 \pm 13$ & $115 \pm 11$ & .373 \\
\hline $\begin{array}{l}\text { Ventilatory support duration } \\
\text { (hours) }\end{array}$ & $99 \pm 23$ & $86 \pm 15$ & 641 \\
\hline ICU stay (days) & $9.5 \pm 1.5$ & $7.4 \pm 0.9$ & .226 \\
\hline Mortality (\%) & 15.4 & 3.9 & .175 \\
\hline
\end{tabular}

Data are shown as the mean \pm standard error of the mean or the percentage of the patients in each group. Myocardial temperature in the group $T$ was the temperature just prior to the start of TWBCP infusion. $C P B$, Cardiopulmonary bypass; $A o X$, aortic crossclamp; $I C U$, intensive care unit.

decreased with TWBCP at 6 and 18 hours after reperfusion compared with the control, indicating TWBCP significantly reduced myocardial necrosis resulting in decreased release of myofibril-bound troponin $\mathrm{T}$ into the serum.

Human h-FABP is a cytoplasmic protein abundant in the myocardial cells, has a lower molecular weight (14.9 kDa) compared with creatine kinase-MB isoenzyme $(80 \mathrm{kDa})$ and troponin $\mathrm{T}(32 \mathrm{kDa})$, and is the key fatty acid carrier protein in the cytosol. ${ }^{13}$ H-FABP is released from cells into the circulation shortly after the onset of cell injury because of 
its low molecular weight and cytosolic location. ${ }^{9}$ Our data showed that h-FABP was significantly decreased at 2 and 3 hours after reperfusion in group $\mathrm{T}$ compared with group $\mathrm{C}$, indicating that less myocardial injury, not always necrosis, occurred with TWBCP.

In physiological conditions, fatty acids, lactate, and glucose are taken from blood into myocardial cells and used as myocardial metabolic substrates. Of these, fatty acids represent the principal metabolic substrate in myocardial cells; however, during ischemia, fatty acid oxidation is inhibited and glycolytic adenosine triphosphate (ATP) production predominates, resulting in lactate production and release into the extracellular space. ${ }^{14}$ Namely, lactate release from the ischemic myocytes is considered as an index of anaerobiosis. Myocardial lactate extraction rate stayed negative in group $\mathrm{C}$, indicating that the amount of lactate production through the anaerobic glycolysis was greater than the amount of lactate used for aerobic energy production. These data indicate continued anaerobic energy metabolism and prolonged impairment of normal aerobic metabolism during the first 60 minutes of reperfusion in hearts receiving cold blood cardioplegia and topical cardiac cooling only. In contrast, our data show that myocardial lactate extraction rate was increased at all time points in group $\mathrm{T}$ compared with group $\mathrm{C}$, and the crossover point of lactate extraction rate from negative to positive was observed at 30 minutes of reperfusion. This indicates that lactate consumption and production were equilibrated at 30 minutes of reperfusion in hearts receiving TWBCP, and thereafter lactate extraction became positive. This crossover point shows that myocardial tissue starts to use lactate as a substrate via oxidative phosphorylation. ${ }^{14}$ These data demonstrate that TWBCP accelerates the recovery of aerobic energy metabolism.

The mechanisms of TWBCP by which TWBCP affords cardioprotection in adult patients have been shown to include the following: (1) warm blood accelerates recovery of temperature-dependent enzymatic and metabolic function and provides oxygen; (2) high potassium prolongs electromechanical arrest to decrease energy demands; (3) low calcium prevents intracellular calcium overload, which is believed to be the major cause of ventricular contracture and reperfusion injury; (4) alkalotic solution counteracts tissue acidosis and optimizes enzymatic and metabolic function; and, (5) high osmolarity counteracts tissue edema., ${ }^{2,6,15-17}$ We have used the same solution as cold blood cardioplegia for TWBCP by just warming cold blood cardioplegia to $35^{\circ} \mathrm{C}$. The composition of our TWBCP solution meets the requirement of above-mentioned proposed mechanisms. At $18 \mathrm{mmol} / \mathrm{L}$, the level of $\mathrm{K}^{+}$was high enough to keep the heart from recurring electromechanical activities, and none of the hearts showed any electromechanical activities during TWBCP infusion.
Because TWBCP is given at the end of global ischemia just before reperfusion, TWBCP is expected to reduce reperfusion injury after ischemia. At the onset of reperfusion after the aortic crossclamp release, we routinely reduced coronary artery perfusion pressure to less than $30 \mathrm{~mm}$ $\mathrm{Hg}$ by partially declamping the aorta for 3 minutes and $\mathrm{Ca}^{2+}$ concentration to less than $0.7 \mathrm{mmol} / \mathrm{L}$ with citratephosphate-dextrose to prevent intracellular calcium accumulation in all patients. Therefore, the major differences in the composition of reperfused solution between the two groups were in potassium concentration, $\mathrm{pH}$, and osmolarity. TWBCP included significantly higher concentration of potassium, higher $\mathrm{pH}$, and higher osmolarity compared with circulating blood at the onset of reperfusion. Thus, we speculate that cardioprotection with TWBCP was achieved with prolonging electromechanical arrest and counteracting myocardial tissue acidosis and edema.

Our results show that TWBCP improved lactate metabolism and reduced myocardial injury and necrosis, and with such mechanisms TWBCP had favorable effects on clinical outcome parameters. The improved lactate metabolism indicates improved aerobic production of high-energy phosphates that would presumably occur through prolonging the electromechanical arrest by high potassium, which reduces energy demands, and through counteracting tissue acidosis. Intracellular acidosis activates $\mathrm{Na}^{+}-\mathrm{H}^{+}$exchanger leading to increased $\mathrm{Na}^{+}$concentration in the cytosol, which would further activate $\mathrm{Na}^{+}-\mathrm{K}^{+}$pump to decrease intracellular $\mathrm{Na}^{+}$ concentration with the consumption of ATP and $\mathrm{Na}^{+}-\mathrm{Ca}^{2+}$ exchanger, leading to increased intracellular $\mathrm{Ca}^{2+}$ concentration. ${ }^{18}$ To reduce intracellular $\mathrm{Ca}^{2+}$ concentration, ATP would be consumed further to activate $\mathrm{Ca}^{2+}$ pumps on the sarcolemma and sarcoplasmic reticulum. Thus, these two constituents of TWBCP, high potassium and high $\mathrm{pH}$, would contribute to the reduced myocardial injury and necrosis by preservation and resynthesis of high-energy phosphates.

The mean age of the patients in this study was $5.6 \pm 0.4$ years, and only 3 neonates were included. Therefore, we could not draw any conclusions in terms of the effect of TWBCP on neonatal hearts, which obviously needs to be elucidated. However, we examined the patients whose ages were equal to or less than 2 years (Table 5 and Figures 5 and 6). Interestingly, our data showed that the crossover point of lactate extraction rate in group $\mathrm{T}$ was observed at $20 \mathrm{~min}-$ utes of reperfusion, which was 10 minutes earlier compared with the entire study group, indicating that the recovery of lactate extraction might be quicker with TWBCP in the younger hearts compared with the older hearts. Cardiac troponin $\mathrm{T}$ was decreased with TWBCP at any time point and the difference between the groups seemed more prominent (Figure 6), although no statistical significance was observed as a result of the small number. These data suggest 
that immature hearts might be provided better myocardial protection by TWBCP compared with mature hearts.

We also examined the patients with cyanosis separately (Table 6 and Figures 7 and 8). Our data showed that no significant differences in lactate extraction were observed between the groups after up to 45 minutes, and the crossover point in group $\mathrm{T}$ was observed between 45 and 60 minutes of reperfusion, indicating that the effect of TWBCP on lactate metabolism was less evident and the recovery of lactate extraction was slower in patients with cyanosis compared with the entire study group. The underlying mechanisms of delayed recovery of lactate extraction could be impaired aerobic energy metabolism or reduced lactate washout ${ }^{19}$ from the hypertrophied myocardium in patients with cyanosis. No significant differences in cardiac troponin $\mathrm{T}$ were observed between the groups at any time point. These data suggest that cyanotic hearts might be less benefited by TWBCP compared with acyanotic hearts. However, the effects and the mechanisms of TWBCP on cyanotic hearts remain to be elucidated.

In conclusion, our data indicate that TWBCP has cardioprotective effects in children and adolescents, as it does in adults, and TWBCP affords an additional myocardial protection by improvement in aerobic energy metabolism and reduction of myocardial injury or necrosis, suggesting that TWBCP would allow for enhanced myocardial protection in pediatric heart surgery and should be used routinely as in adult heart surgery.

We express our appreciation to Sachiko Kido, MD, for assistance with clinical data acquisition and Takako Kanatani, MD, for her administrative assistance. We also wish to extend our appreciation to the physicians in the division of cardiac surgery of Kobe City General Hospital for their assistance.

\section{References}

1. Castaneda AR, Jonas RA, Mayer JE Jr, Hanley FL. Myocardial preservation in the immature heart. In: Castaneda AR, Jonas RA, Mayer JE Jr, Hanley FL, editors. Cardiac surgery of the neonate and infant. Philadelphia: WB Saunders, 1994. p. 41-54.

2. Rao V, Weisel RD. Intraoperative protection of organs: hypothermia, cardioplegia, and cerebroplegia. In: Edmunds LH Jr, editor. Cardiac surgery in the adult. New York: McGraw-Hill, 1997. p. 295-318.

3. Bigelow WG, Callaghan JC, Hopps JA. General hypothermia for experimental intracardiac surgery [abstract]. Ann Surg. 1950;132:531.

4. Yamaguchi M, Imai M, Ohashi H, Hosokawa Y, Tachibana H, Ito H. Enhanced myocardial protection by systemic deep hypothermia in children undergoing total correction of tetralogy of Fallot. Ann Thorac Surg. 1986;41:639-46.

5. Lichtenstein SV, Ashe KA, el Dalati H, Cusimano RJ, Panos A, Slutsky AS. Warm heart surgery. J Thorac Cardiovasc Surg. 1991; 101:269-74.

6. Teoh KH, Christakis GT, Weisel RD, Fremes SE, Mickle DAG, Romaschin AD, et al. Accelerated myocardial metabolic recovery with terminal warm blood cardioplegia. J Thorac Cardiovasc Surg. 1986; 91:885-95

7. Kronon MT, Allen BS, Rahman S, Wang T, Tayyab NA, Bolling KS, Ilbawi MN. Reducing postischemic reperfusion damage in neonates using a terminal warm substrate-enriched blood cardioplegic reperfusate. Ann Thorac Surg. 2000;70:765-70.
8. Roe BB, Hutchinson JC, Ullyot DJ, Smith DL. Myocardial protection with cold, ischemic, potassium-induced cardioplegia. J Thorac Cardiovasc Surg. 1977;73:366-70.

9. Okamoto F, Sohmiya K, Ohkaru Y, Kawamura K, Asayama K, Kimura $\mathrm{H}$, et al. Human heart-type cytoplasmic fatty acid binding protein (H-FABP) for the diagnosis of acute myocardial infarction: clinical evaluation of H-FABP in comparison with myoglobin and creatine kinase isoenzyme MB. Clin Chem Lab Med. 2000;38:231-8.

10. Voss EM, Sharkey SW, Gernet AE, Murakami MM, Johnson RB, Hsieh CC, et al. Human and canine cardiac troponin T and creatine kinase-MB distribution in normal and diseased myocardium. Arch Pathol Lab Med. 1995;119:799-806.

11. Albert B, Bray D, Lewis J, Raff M, Roberts K, Watson JD, editors. Troponin and tropomyosin mediate the $\mathrm{Ca}^{2+}$ regulation of skeletal muscle contraction. Molecular biology of the cell. third edition. New York: Garland Publishing, 1994. p. 854-58.

12. Katus HA, Remppis A, Scheffold T, Diederich KW, Kuebler W. Intracellular compartmentation of cardiac troponin $\mathrm{T}$ and its release kinetics in patients with reperfused and nonreperfused myocardial infarction. Am J Cardiol. 1991;67:1360-7.

13. Schaap FG, van der Vusse GJ, Glatz JFC. Fatty acid binding proteins in the heart. Mol Cell Biochem. 1998;180:43-51.

14. Krause EG, Pfeiffer D, Wollenberger U, Wollert HG. Lactate monitoring during and after cardiopulmonary bypass: an approach implicating a perioperative measure for cardiac energy metabolism. In: Piper HM, Preusse CJ, editors. Ischemia-reperfusion in cardiac surgery. Dordrecht, Netherlands: Kluwer Academic, 1993. p. 317-33.

15. Caputo M, Dihmis WC, Bryan AJ, Suleiman MS, Angelini GD. Warm blood hyperkalaemic reperfusion ("hot shot") prevents myocardial substrate derangement in patients undergoing coronary artery bypass surgery. Eur J Cardiothorac Surg. 1998;13:559-64.

16. Follette DM, Fey K, Buckberg GD, Helly JJ, Steed DL, Foglia RP, et al. Reducing postischemic damage by temporary modification of reperfusate calcium, potassium, $\mathrm{pH}$, and osmolarity. $J$ Thorac Cardiovasc Surg. 1981;82:221-38.

17. Buckberg GD, Allen BS, Beyersdorf F. Blood cardioplegic strategies during adult cardiac operations. In: Piper HM, Preusse CJ, editors. Ischemia/reperfusion in cardiac surgery. Dordrecht, Netherlands: Kluwer Academic, 1993. p. 181-227.

18. Toyoda Y, Khan S, Chen W, Parker RA, Levitsky S, McCully JD. Effects of NHE-1 inhibition on cardioprotection and impact on protection by K/Mg cardioplegia. Ann Thorac Surg. 2001;72:836-43.

19. Jalonen J, Irjala J, Vanttinen E, Inberg MV. Reduced lactate washout from the myocardium after combining St Thomas I type cardioplegia with topical cooling of the heart: myocardial oxygenation and performance after cardioplegia in coronary artery bypass grafting patients. Scand J Thorac Cardiovasc Surg. 1981;15:67-73.

\section{Discussion}

Dr B. Allen (Oak Lawn, Ill). Cardioplegic application in congenital heart surgery has made tremendous gains over the past 10 years; however, recovery and outcome statistics continue to point out the need for improvements in this increasingly younger patient population. In general, advancements in myocardial protection strategies have benefited from the adult cardiac experience. Nevertheless, in view of the structural, functional, and metabolic differences, extrapolation of adult cardioprotective strategies to the pediatric population may be fundamentally imprudent and potentially harmful.

A terminal warm cardioplegic reperfusate is a routine part of most adult heart procedures. In contrast, a warm blood cardioplegic reperfusate is rarely used in infants, perhaps because of the belief that the infant heart is more tolerant to ischemia. Dr Toyoda and his colleagues are to be commended for investigating this question with a randomized clinical trial. These studies are often difficult because, unlike the experimental laboratory where variables can be precisely controlled and measured, the preoperative 